\title{
Recombinant Transforming Growth Factor-Beta
}

National Cancer Institute

\section{Source}

National Cancer Institute. Recombinant Transforming Growth Factor-Beta. NCI

Thesaurus. Code C898.

A recombinant therapeutic agent which is chemically identical to or similar to the endogenous cytokine transforming growth factor-beta (T GF-beta) with proapoptotic and antineoplastic properties. T GF-beta may suppress tumor cell growth by decreasing the expression of cyclin D1, a cell cycle regulatory protein, and downregulating the expression of the oncogene c-myc. This agent is also involved in T cell-mediated immunosuppression by CD4+CD25+ T cells, which permits cancer cells to evade immune surveillance. ( $\mathrm{NCl04)}$ 